Anna Tamara Devic*

Dušan Ristić

Filozofski fakultet

Univerzitet u Novom Sadu
UDK: 78.07 Csáth G.:Bački vesnik“1903/1911" DOI: $10.19090 / g f f .2021 .1 .177-190$

Originalni naučni rad

\title{
NAPISI O MUZICI GEZE ČATA U SUBOTIČKIM DNEVNIM NOVINAMA BAČKI VESNIK (1903-1911)
}

U radu se razmatraju napisi o muzici koje je mađarski novelista Geza Čat objavio u subotičkim dnevnim novinama Bački vesnik (Bácskai Hírlap). Kroz analizu repertoara koncerata koje je posećivao, uočava se njegova težnja ka isticanju nacionalne tradicije u mađarskoj umetničkoj muzici u odnosu na nemačku/austrijsku. Pored toga, primetno je i Čatovo zalaganje za reformu gradskog orkestra Subotice, koji bi bio osposobljen za izvođenje zahtevnijih dela umetničke muzike. Na osnovu analize ovih napisa zaključuje se da je Čat podržavao stvaranje i izvođenje kompozicija onih mađarskih autora koji svoju kompozitorsku delatnost zasnivaju na vlastitoj nacionalnoj tradiciji nezavisnoj od nemačkog uticaja, kao i da je podsticao dalji razvoj muzičkog života u Subotici, koja se u odnosu na Budimpeštu nalazila na periferiji muzičkih dešavanja.

Ključne reči: Geza Čat, Bački vesnik (Bácskai Hírlap), nacionalna tradicija, muzički život, Budimpešta, Subotica

\section{UVOD}

Novelista i neuropsihijatar Geza Čat (Csáth Géza, 1887, Subotica, Austrougarska - 1919, Kelebija, Kraljevina SHS), danas je prvenstveno poznat po svom književnom radu, odnosno novelama koje se smatraju remek-delima (Bori, 1979: 267-309; Szajbély, 1989; Szajbély, 2019). Manje je, međutim, poznato da je Čat autor i mnogobrojnih kritika posvećenih muzičkim događajima u Subotici i Budimpešti, kao i stručnih članaka o razvoju mađarske nacionalne umetničke muzike početkom 20. veka. Za sada je malo pažnje posvećeno naučnoj analizi muzikografske delatnosti ovog darovitog kritičara (Csáth, 1971; Csáth, 1975; Csáth, 1977; Csáth, 2000; Kelemen, 2015), koji je po ličnoj kulturi i muzičkom talentu bio predodređen za muzičkog pisca.

*anna.devic92@gmail.com, risticd@ff.uns.ac.rs 
Geza Čat je umetničko ime Jožefa Brenera mlađeg (ifj. Brenner József), najstarijeg deteta advokata, koji je od 1902. bio na funkciji javnog tužioca grada Subotice. Jožef Brener stariji je voleo muziku i veoma aktivno je učestvovao u muzičkom životu ovog grada. Bio je osnivač i dirigent Subotičkog pevačkog društva (Szabadkai Dalegyesület), organizovao je koncerte i pisao prigodne kompozicije (Kelemen, 2015: 14). S toga ne iznenađuje da se Geza Čat, od detinjstva okružen muzikom, nakon završene gimnazije u rodnoj Subotici opredeljuje za studije muzike. Međutim, ne uspeva da položi prijemni ispit na Muzičkoj akademiji u Budimpešti, pa se upisuje na Medicinski fakultet (1904). Uprkos tome i dalje se bavi komponovanjem i pisanjem muzičkih kritika. Od 1906. sarađuje sa vodećim dnevnim listovima i časopisima koji su izlazili u glavnom gradu Ugarske, ${ }^{1}$ ali muzičke kritike i dalje objavljuje u subotičkom Bačkom vesniku (Bácskai Hírlap), dnevnim novinama u kojima je već 1903. započeo svoju publicističku delatnost.

Zanimljivo je da je u Subotici izlazilo nekoliko novina sa nazivom Bački vesnik: od 1880. je nedeljnik Subotički bilten (Szabadkai közlöny) neko vreme štampan kao Bački vesnik (Kolozsi, 1973: 530, 549); drugi Bački vesnik je bio društveni, obrazovni i književni nedeljnik subotičkog omladinskog kružoka, koji je izlazio u periodu od 1880. do kraja 1881.; treći Bački vesnik, u kojem je i Čat objavljivao svoje napise, izlazio je od 3. oktobra 1897. do početka 1919., kada je ukinut. Ovaj Bački vesnik pokrenut je kao list o društvenim, ekonomskim i književnim problemima i izlazio je četiri puta nedeljno. Međutim, već dva meseca nakon nastanka (17. decembra 1897.) postaje politički list, a od 6. aprila 1902. dnevni politički list, koji je izlazio svakodnevno osim ponedeljkom. Tibor Koloži (Kolozsi Tibor) navodi da je od 1906. do 1909. Bački vesnik bio glasilo Nezavisne stranke Bačko-bodroške županije (Kolozsi, 1973: 530-531).

U monografiji o Gezi Čatu književni teoretičar Mihalj Sajbelj (Szajbély Mihály) konstatuje da je za Čata u to vreme, između 1903. i 1906., novinarstvo predstavljalo samo hobi i da mu je bilo zanimljivo da za novine piše o različitim temama - od umetničkih do političkih. ${ }^{2}$ Uprkos tome, „Čat nikada nije postao profesionalni novinar i nikada nije radio kao unutrašnji saradnik nekog lista. Iz široke lepeze karijere jednog početnika, od samog početka su se izdvojila dva područja unutar kojih su ga ubrzo smatrali profesionalcem: novela i muzička kritika.“(Szajbély, 1989: 25)

\footnotetext{
${ }^{1}$ Magyar Szemle, Budapesti Napló, A Polgár, Nyugat, Világ, itd.

${ }^{2}$ O političkim sadržajima Čatovih novinskih tekstova vidi: Szajbély, 1989: 25-34.
} 


\section{ZALAGANJE ZA NACIONALNU TRADICIJU U UMETNIČKOJ MUZICI}

U periodu od 1903. do 1911. Čat je u Bačkom vesniku objavio dvadeset $\mathrm{i}$ pet tekstova o muzici (vidi prilog). Njihova glavna karakteristika je kolažnost, dok u sadržinskom pogledu dominiraju muzičke kritike koncerata koje je posećivao, protkane njegovim dubljim, estetskim razmišljanjima o muzici i izvođačima. Ono što odmah pada u oči u Čatovim prvim kritikama jeste njegovo zalaganje za češće izvođenje kompozicija mađarskih autora, uz oštrije suprotstavljanje tada još dominantnom nemačkom/austrijskom uticaju. U skladu sa tim, Čat pozdravlja koncert Subotičkog pevačkog društva održanog 23. februara 1903. (1), ${ }^{3}$ kao i nastup solo pevačice Tereze Kramer (Krammer Teréz) iz Budimpešte, koja je izvela i ariju iz opere Laslo Hunjadi mađarskog kompozitora Ferenca Erkela (Erkel Ferenc):

Predivna koloratura, napisana ogromnom snagom. Kada je predivna dama nastupila da je otpeva - dočekao ju je aplauz. Čuli smo mađarsku muziku mađarskog kompozitora (ovo dvoje retko ide zajedno). Osećajni duboki tonovi i predivno odzvanjajući visoki glasovi slili su se u izvanrednu ariju i dirnuli su nas u srce. Nakon vrlo teške kadence iz redova publike začulo se prigušeno divljenje. (Csáth, 2000: 571)

Nekoliko meseci kasnije, Čat pohvalno komentariše i program sa završnog koncerta Učiteljske škole u Subotici (2):

Nastavnici Emi Volski upućujemo pohvalu za veoma raznolik i s velikim ukusom i umetničkim osećajem sastavljen program (od devet numera šest su dela mađarskih autora), kao i za njihovu pripremu. (Csáth, 2000: 573)

Iako studira u Budimpešti, Čat i dalje prati dešavanja i koncerte u rodnom gradu i izveštava o njima. Kao primer ove neprekinute zainteresovanosti za stanje muzičke kulture u Subotici izdvaja se njegov prikaz koncerta održanog u Subotičkoj gimnaziji 18. decembra 1904. (6), koji je organizovao krug subotičkih pokrovitelja umetnosti u korist nabavke klavira za gimnaziju. U prvom delu napisa Čat ukazuje na trenutno stanje muzičkog obrazovanja u gimnaziji, iz čega se može nazreti njegov, tada još romantičarsko-didaktički i prosvetiteljski odnos prema problemu o kojem piše:

Neprijatno iznenađenje! Ova gimnazija još nema klavir? Zašto ga nema, iako je potreban poput klupa, tabli, knjiga i nastavnika!? (...) Zar obrazovanom čoveku nije potrebna muzička edukacija? I ako nije muzičar, kako da je stekne? Srednja škola

\footnotetext{
${ }^{3}$ Broj u zagradi označava izvorni tekst u Bačkom vesniku, čiji je spisak dat u prilogu.
} 
je ovde u obavezi. Kao što objasni Rafaela, Mikelanđela, Leonarda, Šekspira, nastavnik istorije umetnosti treba da objasni i Baha, Betovena, Mocarta, Vagnera. Pa to se podrazumeva, kažete vi. Nakon toga bi trebalo da uvede učenike u muzički kabinet da poslušaju Patetičnu sonatu ili Apasionatu u izvođenju nekog od njihovih drugara ili nastavnika muzike - koji im tada i objasni to delo. Možda će zvučati neobično ako vam kažem da to nije tako: o muzici nema ni govora u okviru estetike; srednjoškolce u tom pogledu obrazuju vojni orkestri i Romi. ${ }^{4}$ (Csáth, 2000: 237)

Nakon prosvetiteljskog dela teksta, Čat komentariše i sam koncert. Njegova jedina zamerka odnosi se na repertoar na kojem dominiraju dela nemačkih kompozitora, što ukazuje na to da se Čat dosledno zalaže za promovisanje dela iz vlastite, mađarske nacionalne tradicije:

[I]mena Bloha, Vajta i Šmidta bi tu mogla da se nađu samo ako bi imala isti onaj značaj koji imaju imena Betovena ili Vagnera, jer od ove gospode postoje mnogo bolji mađarski kompozitori. (Csáth, 2000: 237)

„Antinemački“ - zapravo antibečki - stav u ovim Čatovim ranim napisima ne treba da iznenadi, jer je u skladu sa opštom političkom klimom u Ugarskoj na prelazu iz 19. u 20. vek. Vladajuća austrijska dinastija Habzburga je zanemarivala nacionalnu nezavisnost, kao i mnoga prava koja je Ugarska stekla prilikom Nagodbe (šire vidi Tejlor, 2001: 159-165). Zbog toga se u celom mađarskom društvu - a posebno u politici i kulturi -, aktivno promovisala ideja o nacionalnom, uz istovremeno prikriveno ili otvoreno iskazivanje mržnje prema Habzburzima (Tejlor, 2001: 209220).

Tokom 19. veka muzički život u Budimpešti prošao je kroz velike promene, koje su posebno intenzivne u sklopu sveopšte modernizacije mađarskog društva nakon Nagodbe 1867. i konstituisanja dvojne monarhije (šire vidi: Rokai, Đere, Pal, Kasaš, 2002; Babić, 2009). Osnovane su muzičke institucije, stvarala se i edukovala umetnička publika, razvilo se notno izdavaštvo i proizvodnja instrumenata, javlja se muzička kritika, a i broj gostovanja renomiranih svetskih umetnika neprekidno raste. U periodu Čatovog intenzivnog kritičarskog rada (1906-1912), u Budimpešti su nastupali i najznačajniji svetski umetnici: pijanisti Raul Punjo (Raoul Pugno) i Vilhelm Bakhaus (Wilhelm Backhaus), violinisti Jan Kubelik (Jan Kubelik) i Vili Burmešter (Willy Burmester), violončelista Pablo Kazals (Pablo Casals), solo

\footnotetext{
${ }^{4}$ U originalu stoji Cigani (cigányok); Čat u stvari misli na cigansku muziku (cigányzene), bez vrednosno negativnog značenja prema romskoj populaciji i njihovoj muzičkoj kulturi.
} 
pevačice Ivet Gilber (Yvette Guilbert) i Marija Labija (Maria Labia) i mnogi drugi (šire vidi: Bónis, 2005; Szerző, 2011).

Koncerti umetničke muzike u Budimpešti izvodili su se na više mesta, od kojih su najznačajnije koncertna dvorana Vigado (Vigadó, 1865), Muzička akademija (Zeneakadémia, 1875), Mađarska državna opera (Magyar Állami Operaház, 1884) i sala Hotela Rojal (Royal Szálló terme, 1896). Za vreme boravka u Budimpešti Čat redovno posećuje ove institucije i značajan broj kritika i eseja o muzici napisao je baš o dešavanjima koja su u njima održana. U periodu od 1904.1906. Čat subotičku publiku izveštava o koncertima violinista Ferenca Večeija (Ferenc Vecsei), Pabla de Sarasatea (Pablo de Sarasate) i Vilija Burmeštera, pijaniste Emila Zauera (Emil Sauer), solo pevačice Šare Petraš (Sari Petráss), kao i o izvođenjima kompozicija Pongraca Kačoha (Kacsóh Pongrác), Imrea Kalmana (Kálmán Imre), Bele Bartoka (Bartók Béla) i drugih.

Isticanje nacionalnog, odnosno insistiranje na mađarskoj muzičkoj tradiciji naspram nemačke/austrijske do izražaja dolazi i u tekstovima u kojima Čat komentariše izvođenja dela navedenih mađarskih kompozitora. Tako u tekstu objavljenom 1905. u Bačkom vesniku (9) povodom 150. izvođenja muzičke igre (nem. Singspiel) Janoš vitez (János vitéz) Pongraca Kačoha, Čat skreće pažnju Subotičana na značaj i originalnost ovog kompozitora: ${ }^{5}$

Napokon jedan kompozitor opera koji ima vlastite ideje i koji nije samo učio, već i zna šta je mađarski stil. A moramo da dodamo da kod nas još nijedna opera nije imala ovako dobar libreto. I eto, nastala je. Jer je Janoš Vitez opera: muzička igra. Onaj ko u to ne veruje neka pogleda originalnu partituru u kojoj blistaju mnogobrojne veštine, a naročito ozbiljne ideje. (. . .) Da, napokon ponovo imamo i jednu ličnost među mađarskim muzičarima, a ličnost moramo više da cenimo od svake druge osobine. Kačoh po ideje ne ide u Bajrojt, niti u Beč, Rim ili Pariz, on ih uzima iz sebe; jer ih ima. (Csáth, 2000: 47-48)

Slično razmišlja i muzički kritičar dnevnih novina Mađarska nacija (Magyar Nemzet), ${ }^{6}$ koji još 18 . novembra 1904. na premijeri ovog dela pozdravlja Kačohov postupak primene elemenata mađarske narodne muzike. Pored toga što ističe da je

\footnotetext{
5 Pongrac Kačoh (1873-1923), mađarski kompozitor i muzički pedagog. Bio je među prvima koji su prepoznali značaj Bartokove muzike (Zenevilág, 1904). (Kacsóh Pongrác, 1967: 833-834).

${ }^{6}$ Mađarska nacija (Magyar Nemzet), nezavisne novine koje su izlazile između 1899. i 1913. u Budimpešti. (https://adtplus.arcanum.hu/en/collection/MagyarNemzetJokaiBeksicsUgron/ pristupljeno 6.9.2020.)
} 
ovo Kačohovo delo, kako u pogledu teksta koji je napisao mađarski književnik Petefi (Petőfi Sándor), tako i u pogledu muzike u potpunosti mađarsko, navodi da će se „nakon engleske, francuske, američke, a iznad svega premnogo austrijske muzike, čuti nešto sasvim drugo, nešto u potpunosti novo" (R. I., 1904: 6). Jer, nastavlja ovaj kritičar, „bilo bi zaista teško zamisliti Petefijevo delo u pratnji bečkih valcera, pariskih šansona ili u pratnji engleskog i američkog baleta" (R. I., 1904: 6). Povodom premijere Janoš viteza i autor teksta u nedeljniku Svet (Ország-Világ) konstatuje Kačohovu pravilnu upotrebu mađarskih narodnih pesama: „U ovoj muzici odzvanja duša naših narodnih pesama, čuvajući svoj besprekorno čist karakter i u najrazvijenijim muzičkim formama, ne menjajući se, postajući samo prefinjenija i rečitija." (János vitéz, 1904: 955) ${ }^{7}$

Čat iz Budimpešte subotičku publiku izveštava i sa dobrotvornog koncerta (10), koji je 2. aprila 1905. organizovalo Državno udruženje mađarskih ljubitelja muzike (Magyar Zenekedvelők Országos Egyesülete) na čelu sa kompozitorom Jeneom Stojanovičem (Sztojanovits Jenő), a u saradnji sa Budimskim pevačkim društvom. Osim Grigove svite Per Gint (Peer Gynt), na repertoaru su bile isključivo kompozicije mađarskih autora. Izvedena je uvertira iz Potonulog grada ( $A z$ elsüllyedt város) Jožefa Feketea (Fekete József), Pesma o pesmi (Dal a dalról) Gvida Pogačniga (Pogatschnigg Guido), Saturnalija (Szaturnália) Imrea Kalmana, Velika mađarska uvertira (Nagy magyar nyitány) Lasla Toldija mlađeg (ifj. Toldy László), Mađarska pesma (A magyar nóta) Jenea Stojanoviča i Dva orkestarska komada (Két zenekari darab) Andora Merklera (Merkler Andor). Od ovih dela Čat komentariše samo tri: kompozicije Kalmana, Feketea i Toldija mlađeg. Pišući o Kalmanovim Saturnalijama, Čat ističe njegov talenat i smelo ga pozicionira među buduće značajne aktere mađarske muzičke scene:

[U] potpunosti originalan je Imre Kalman (. . .) Biće on jedan od najznačajnijih i najistaknutijih stvaralaca mađarske muzike. O ovom njegovom delu - čiji je sadržaj neumetnički i neukusno prepričavati (kao što je to i inače slučaj sa sadržajem slika, skulptura i muzičkih dela) - samo još toliko da, uz savršeno baratanje orkestrom, pronalazimo i takvo obilje polifonih invencija koje Kalmana stavljaju odmah uz Bartoka. Ovakvi ljudi su potrebni mađarskoj muzici. (Csáth, 2000: 239)

7 Svet (Ország-Világ, 1879-1938.) budimpeštanski informativni i književni ilustrovani nedeljnik; pored Nedeljnih novina (Vasárnapi Ujság) bio je jedan od najznačajnijih časopisa u Ugarskoj, koji su izlazili nakon Nagodbe.

( < https://adtplus.arcanum.hu/en/collection/OrszagVilag/ > pristupljeno 6.9.2020.) 
Naspram Kalmana, Čat negativno ocenjuje kompozicije Jožefa Feketea i Lasla Toldija mlađeg. On u njihovim delima ne vidi originalnost $u$ motivima i orkestraciji, već samo imitaciju nemačkog kompozitora Riharda Vagnera (Richard Wagner):

Nažalost, isti ovi ljudi u tretmanu velikog orkestarskog aparata ne razmišljaju svi na mađarskom. Nije problem ako neko komponuje međunarodnu muziku, all right, ali ako mu je i pored sposobnosti stečenih istrajnošću i velikim učenjem potreban Bajrojt, to nije samo neobično, već je i problem. Jožef Fekete, koji prelepo barata orkestrom, ljuti je sledbenik Vagnerovog jevanđelja, u kojem je do sada samo Vagner pronašao spasenje. I Laslo Toldi mlađi je njegov predani sledbenik, ne samo u tretmanu orkestra i primeni motiva, već i u melodijskim konstrukcijama. (Csáth, 2000: 238)

$\mathrm{Na}$ desetom koncertu Filharmoničara, koji je održan 15. marta 1905. u dvorani Vigado izveden je Skerco, jedini završen stav Simfonije u Es-duru (BB 25) Bele Bartoka (10). Čat se pohvalno izrazio o ovoj kompoziciji, ističući njenu originalnost i modernost:

Ono što je zanimljivo i izvanredno, a možda će nakon ovoga postati i večno, vezuje se za jedno potpuno novo ime, za ime jednog genija: Bele Bartoka (. . .). Jer njegov, u velikom stilu i grandiozno komponovan Skerco zvučao je kao jedan snažan, moćan zahtev kojim na kapiju besmrtnosti udara jedan mršavi, dugokosi Mađar sa licem glumca. Onaj ko je čuo ovo istinski originalno i moderno delo klasicizam budućnosti -, ne može da sumnja u talenat Bele Bartoka. Jer imamo mi kompozitore u prevelikom broju, ali vrlo malo onih koji stvaraju originalna i velika dela. (Csáth, 2000: 238)

O Bartokovoj originalnosti 1904. govori i muzički kritičar dnevnih novina Mađarska (Magyarország), ${ }^{8}$ koji povodom premijere Skerca piše da ovo delo „daje vernu sliku o genijalnoj ličnosti mladića smele fantazije. Ovaj Skerco je pun originalnosti, pun je boja i živahnosti." (Fiatal zeneszerzők hangversenye, 1904: 12.) O koncertu o kojem je Čat pisao, izveštava i kritičar Peštanskog dnevnika

${ }^{8}$ Mađarska (Magyarország) je bio politički dnevni list. Izlazio je između 1894. i 1944. u Budimpešti.(https://adtplus.arcanum.hu/en/collection/Magyarorszag/pristupljeno 6.9.2020.) 
(Pesti Napló $)^{9}$ : „Bartokova muzika je puna ideja, energije i mladosti. Ovo je proba snage stvaraoca sigurne ruke, snažne volje i otvorenog vidika. Koncepcija ovog dela je prelepa; tako je monumentalno, tako je smelo i tako je čvrstog sleda misli, kao kod velikih majstora.“ (K. I., 1905: 15) Jedina zamerka odnosi se na formu dela, za koju ovaj kritičar smatra da nije originalna, nego je imitacija 3. stava (Skerca) Betovenove 9. simfonije. Sa njihovim mišljenjem podudara se i komentar muzičkog kritičara novina Mađarska nacija, koji u Bartokovom Skercu, uprkos tome što je ,još pun mladalačkih ludosti“, uočava veliku fantaziju, koja „već dopušta da se nasluti ogroman talenat mladog umetnika“. (Filharmóniai hangverseny, 1905: 8) Na osnovu ovih komentara možemo da vidimo da se i mišljenja drugih kritičara u velikoj meri poklapaju sa mišljenjem Geze Čata o mladom Bartoku i njegovom Skercu, ali jedino Čat uočava moderni karakter ovog dela.

\section{ZALAGANJE ZA RAZVOJ MUZIČKOG ŽIVOTA SUBOTICE}

Za vreme studija Čat je u Bačkom vesniku objavio i dva članka o muzičkom životu u Budimpešti: „Muzički život u Budimpešti“ (16) i „Muzika i moderan život" (18), kao i jedan o muzičkom životu Subotice, "Stanje muzičkog života u Subotici“ (19). Zahvaljujući ovim tekstovima čitaoci Bačkog vesnika imali su priliku da upoznaju opšte stanje i stepen razvijenosti muzičke kulture u oba grada. U prvom od gorenavedenih tekstova (,Muzički život u Budimpešti“) Čat intenzivni razvoj muzičkog života u glavnom gradu Ugarske pripisuje želji za napretkom i opštoj potrebi za muzikom na početku 20. veka, koja je zahvatila i stanovnike ovog grada:

Ovi ljudi su ispunili nešto obavezujuće. Osetili su dah one budućnosti kada će muzika, poput jezika, postati svačija; osetili su da će doći vreme kada više nećemo moći bez muzike, jer da bismo opstali u uslovima duhovne opterećenosti života, moramo da proširimo i naš duhovni jelovnik. Osetili su koliko bi oni, ali i njihovi potomci izgubili ako ne bi u celini prisvojili plemenite užitke života i uzeli ih u svoje vlasništvo. I tako je Budimpešta krenula u pravcu muzike. Za nekoliko godina nastala je velika koncertna publika. Čovek bi nehotice pomislio da u nama

\footnotetext{
${ }^{9}$ Peštanski dnevnik (Pesti Napló) bio je politički dnevni list, a izlazio je od 1850. do 1939. u Budimpešti. Njegovo osnivanje smatra se najvažnijim događajem u istoriji novinarstva u decenijama nakon revolucije 1848/49.
}

(https://adtplus.arcanum.hu/en/collection/PestiNaplo/ pristupljeno 6.9.2020.) 
postoji stalna namera da za dvadeset i četiri sata nadoknadimo sve ono što naši dedovi i očevi stolećima nisu uradili. (Csáth, 2000: 167-168)

U sledećem tekstu, „Muzika i moderan život“, razloge za unapređenje muzičkog života u glavnom gradu Ugarske Čat pronalazi i u kvalitetnoj umetničkoj muzici, koja odgovara potrebama čoveka 20. veka:

Duhovni život savremenog čoveka se sve više komplikuje. Tražimo teorije koje bi nas usrećile, želimo da odmorimo usamljenu lađu naše napaćene duše u luci uživanja u kojoj nema uzbuđenja. Potrebna nam je nekakva harmonija, nekakva dopuna. A to nam se dobrovoljno nudi u muzici. U dobroj umetničkoj muzici. (Csáth, 2000: 171)

Nasuprot Budimpešti, Čat razočarano konstatuje zaostalost muzičkog života u Subotici u to vreme:

Ono što imamo da kažemo može se sažeti u nekoliko reči: Grad Subotica je u muzičkom pogledu veoma zaostao. U trećem gradu u državi nismo čak ni tamo gde smo bili pre pedeset godina. (Csáth, 2000: 171)

Svestan da se mnogi ne bi složili sa ovom tvrdnjom, jer je muzička škola u Subotici odnegovala znatan broj kako ljubitelja, tako i onih koji se profesionalno bave muzikom (šire vidi: Pekár, 2002), on je potkrepljuje sledećim argumentima:

Kućno muziciranje i koncerti Pevačkog društva koji su eventualno povezani sa nekim datumima, ne mogu da zadovolje publiku koja je u potpunosti dete XX veka. Grand art muzike: istinski plemenita simfonijska muzika i dragocena, prava crkvena muzika ovde su praktično u potpunosti nepoznate. Međutim, ovu muziku treba obezbediti. Treba je institucionalno obezbediti! (Csáth, 2000: 172)

U tom pravcu Čat iznosi i produbljenu kritiku jedine dve muzičke institucije u Subotici: gradskog/crkvenog orkestra i muzičke škole: „Obe su stare organizacije, stare tvorevine, koje se uopšte nisu prilagodile naprednijim zahtevima naprednijeg vremena.“ (171) Kako saznajemo iz ovog Čatovog napisa, iako je u Subotici u to vreme već bilo nagoveštaja o mogućoj izgradnji Doma kulture, uređenju javne biblioteke i izgradnji nove muzičke škole, on smatra da gradski/crkveni orkestar zahteva najhitniju reformu, jer je u ovakvom obliku „u potpunosti neupotrebljiv“ (172), odnosno „ne može izvesti nikakvo značajnije delo koje je napisano za orkestar (ili za tzv. mali orkestar)“. (172) Čatov predlog za rešenje ovog problema je proširenje orkestra zapošljavanjem bar još sedam-osam muzičara, od kojih šestoro treba da budu duvači. U nastavku teksta, Čat spominje i Ernea Lanjija (Lányi Ernő), čuvenog muzičkog pedagoga i kompozitora, koji je preuzeo funkciju direktora muzičke škole, kao i upravu nad već spomenutim gradskim orkestrom 
(šire vidi: Devic, Lazar, 2020). Međutim, tvrdi Čat, ukoliko ne bude ozbiljne finansijske i institucionalne podrške od skupštine grada, ni ovako istaknuta ličnost neće biti sposobna da ozbiljnije unapredi muzički život Subotice. Čat, dakle, apeluje da se institucionalno reši finansiranje novih članova orkestra, jer bi se samo na taj način stvorili potrebni uslovi za razvoj kvalitetnog muzičkog života $u$ Subotici, koji bi ujedno bio i osnova za unapređenje celokupnog kulturog života grada.

$* * *$

Čatova zalaganja za razvoj muzičkog života Subotice u tekstovima objavljenim u Bačkom vesniku narednih godina urodila su plodom. Zahvaljujući Erneu Lanjiju subotički gradski orkestar transformisan je u Subotičko Filharmonijsko Društvo (Szabadkai Fiharmóniai Társaság), prerastavši u kvalitetan simfonijski orkestar. Takođe, u periodu od 1907.-1914. u Subotici su gostovali i nastupali neki od najznačajnijih mađarskih i svetskih muzičkih umetnika: violinistkinja Štefi Gejer (Geyer Stefi) i violinista i kompozitor Jene Hubai (Hubay Jenő), solo pevačica Ilona Durigo (Durigo Ilona), pijanista i kompozitor Bela Bartok, pijanista i profesor na Mađarskoj muzičkoj akademiji Arpad Sendi (Szendy Árpád), violončelista Jene Kerpelj (Kerpely Jenő), ${ }^{10}$ zatim švedska solo pevačica Valborg Svardstrem (Valborg Svärdström) i španski violončelista Pablo Kazals (vidi: Pekar, 2002: 146-161).

Možemo, dakle, sa izvesnošću da tvrdimo da je raznovrsnost i višeslojnost Čatovih napisa objavljenih u Bačkom vesniku bila u funkciji podsticanja razvoja muzičkog života u Subotici. U dvadeset i pet tekstova, koje je objavio u ovim dnevnim novinama u periodu od osam godina, Čat je sazrevao od romantičarski orijentisanog gimnazijalca do zrelog noveliste i jednog od vodećih muzičkih kritičara Ugarske tog vremena. Njegovi napisi o muzici predstavljaju značajne dokumente o vremenu u kojem je živeo, jer svedoče o muzičkim i kulturnim praksama kojima su težili obrazovani građani kulturne periferije, kakva je bila i Subotica na početku 20. veka.

\footnotetext{
${ }^{10}$ Jene Kerpelj je bio član sastava Valdbauer-Kerpelj (Waldbauer-Kerpely), najznačanijeg gudačkog kvarteta u Ugarskoj u prvoj polovini 20. veka. Izvodili su pre svega dela savremenih autora, pomogavši afirmaciji između ostalih i Bele Bartoka i Zoltana Kodalja (Kodály Zoltán).
} 
Anna Tamara Devic, Dušan Ristić

GÉZA CSÁTH'S WRITINGS ON MUSIC IN THE SUBOTICA DAILY NEWSPAPER BAČKI VESNIK (1903-1911)

\section{Summary}

The paper discusses articles about music published by the Hungarian novelist Géza Csáth in the Bački vesnik (Bácskai Hírlap), the daily newspaper of the city of Subotica in which he began his publishing career. In the period from 1903 to 1911, Csáth published twenty-five texts about music in this newspaper. Their main characteristic is collage, while in terms of content, they are dominated by the musical critiques of the concerts he attended, interwoven with his deeper, aesthetic reflections on music and performers.

The analysis of these texts shows that Csáth was especially committed to: 1) strengthening the national tradition in Hungarian art music in relation to German/Austrian, 2) the development of musical life in Subotica. Advocacy for the national tradition was common at the beginning of the $20^{\text {th }}$ century in Hungary. Commenting the repertoires of the concerts he attended, Csáth also insists on the use of elements of Hungarian folk music in the opuses of Hungarian composers, as well as on their independence from German art music. The paper discusses Csáth's comments on compositions by Pongrác Kacsóh and Imre Kálmán, who correctly use elements of Hungarian folk music in their work, as well as pieces by Jozsef Fekete and László Toldi Jr., which, in Csáth's opinion, are examples of composing under the influence of German music tradition and particularly Richard Wagner. Csáth's article about the concert performance of Béla Bartók's Scherzo is also analyzed, and his comments are compared with the comments of other Hungarian music critics who also reported on the performance of this piece. Although their opinions are basically in agreement, Csáth is the only one who noticed the modern character of this work by Bartók.

Csáth also published articles about the musical life in Budapest and Subotica in Bački vesnik. Comparing the general situation and the level of development of music culture in both cities, he disappointedly states the backwardness of Subotica and demands from the city authorities an urgent reform of the city orchestra, which would be capable of performing more demanding works of art music. According to Csáth, only in that way would the necessary conditions be created for the further development of musical life in Subotica, which would also be the basis for the improvement of the entire cultural life of the city. His writings on music are important documents about the time in which he lived, because they testify to the musical and cultural practices pursued by educated citizens of the cultural periphery, such as Subotica at the beginning of the $20^{\text {th }}$ century.

Keywords: Géza Csáth, Bački vesnik (Bácskai Hírlap), national tradition, musical life, Subotica, Budapest 


\section{LITERATURA}

Babić, Sava (2009). Mađarska civilizacija. Senta: Nacionalni savet mađarske nacionalne manjine, Zavod za kulturu vojvođanskih Mađara.

Bori, Imre (1979). A 'homo novus' nagysága és tragédiája. Varázslók és mákvirágok. Újvidék: Fórum Könyvkiadó, 267-309.

Bónis, Ferenc (2005). A Budapesti Filharmóniai Társaság százötven esztendeje 1853-2003. Budapest: Balassi kiadó.

Csáth, Géza (1975). Írások az élet jó és rossz dolgairól: kritikák, cikkek, karcolatok, (ur. Dér Zoltán), Szabadka: Munkásegyetem.

Csáth, Géza (1977). Ismeretlen házban II - Kritikák, tanulmányok, cikkek. (ur. Dér Zoltán), Újvidék: Forum Könyvkiadó.

Csáth, Géza (2000). A muzsika mesekertje. (ur. Szajbély Mihály), Budapest: Magvető Könyvkiadó.

Csáth, Géza (1971). Éjszakai esztetizálás. (ur. Demény János), Budapest: Zenemükiadó.

Devic, Anna Tamara, Lazar, Zsolt (2020). Ernő Lányi in Music Critiques by Géza Csáth (1906-1912). Godišnjak Filozofskog fakulteta u Novom Sadu, knj. XLV (1), 191-207.

Fiatal zeneszerzők hangversenye (1904). Magyarország, (1904. március 2.), 11. évfolyam, 53. szám, 12.

Filharmóniai hangverseny (1905). Magyar Nemzet, (1905. március 17.), 24. évfolyam, 68. szám, 8.

János Vitéz (1904). Ország-Világ, (1904. november 17.), 25. évfolyam, 48. szám, 955.

Kacsóh, Pongrác (1967), Á. Kenyeres (szerk.), Magyar Életrajzi Lexikon (1. kötet). Budapest: Akadémiai Kiadó.

K. I. (1905). Filharmóniai hangverseny. Pesti Napló, (1905. március 16.), 56. évfolyam, 75. szám, 15.

Kelemen, Éva (2015). Müvészetek vándora, A zeneszerzö Csáth Géza. BudapestGyőr: OSZK-Magyar Kultúra Kiadó.

Kolozsi, Tibor (1973). A szabadkai sajtó (1848-1919). Szabadka: Életjel.

Pekár, Tibor (2002). Szabadka zenei élete (1900-1918): adalékok a város zenei múltjának történetéhez. Szabadka: Szabadegyetem.

R. I. (1904). János Vitéz. - A Király-Szinház premiérje. Magyar Nemzet, (1904. november 19.), 23. évfolyam, 277. szám, 6.

Rokai, Peter, Đere, Zoltan, Pal, Tibor, Kasaš, Aleksandar (2002). Istorija Mađara. Beograd: Clio. 
Szajbély, Mihály (1989). Csáth Géza. Budapest: Gondolat Könyvkiadó.

Szajbély, Mihály (2019). Csáth Géza élete és munkái - Régimódi monográfia. Budapest: Magvető Kiadó.

Szerző, Katalin (2011). Zenei élet a dualizmus korában. Kárpáti János (ur.), Képes magyar zenetörténet, Budapest: Rózsavölgyi és Társa.

Tejlor, Alan (2001). Habzburška monarhija, Beograd, Clio. 
PRILOG: Napisi o muzici Geze Čata objavljeni u Bačkom vesniku (1903-1911) ${ }^{11}$

1) A Szabadkai dalegyesület Krammer-estélye, 1903. február 25. 3.

2) Hangverseny a tanítóképzőben, 1903. június 3. 2-3.

3) Kóczé, 1904. augusztus 3. 1-2.

4) Eötvös, a magyar zene és egyebek, 1904. augusztus 4. 2.

5) Vecsey Ferenc, 1904. október 16. 8.

6) Hangverseny a gimnáziumban, 1904. december 21. 4.

7) Budapesti levél. Sauer Emil, Szinyei Merse Pál, Petráss Sári, 1905. február 12. 7.

8) Budapesti levél. Sarasate, Lotz Károly, 1905. március 12. 7-8.

9) A János vitéz, 1905. április 2. 7.

10) Budapesti levél két hangversenyröl, 1905. április 11. 2-3.

11) ifj. Lályi Ernő: Virágénekek, 1905. október 7. 4.

12) Budapesti levél. Burmester hangversenye, 1905. november 12. ?

13) A koldusdiák, 1905. december 21.4-5.

14) Gül-baba, 1906. január 14. 9.

15) Fráter Lóránt dalestélye a Nemzeti Kaszinóban, 1906. január 21. 7.

16) Budapest zenei élete, Magyar Szemle, 1906. október 4. 639.; Bácskai Hírlap, 1906. október 14. 8.

17) Hangverseny a színházban, Bácskai Hírlap, 1907. április 4. 1-2.

18) A muzsika és a modern élet, 1907. április 7. 5-6.

19) Szabadka zenei állapotai, 1907. június 19. 1.

20) Grieg, 1907. szeptember 6. 2.

21) Filharmonikus hangverseny, 1908. április 14. 1-2.

22) Zenei közművelődés, Vasárnapi Újság, 1908. április 26. 335-336.; Bácskai Hírlap, 1908. július 12. 2-3.

23) Vén cigányok, Nyugat, 1908. november 1.; Bácskai Hírlap, 1908. november 8. 7.

24) Lányi Ernő új dalai, Nyugat, 1909. február 1. 172-173.; Bácskai Hírlap, 1909. február 7. 4.

25) Lányi Ernő új dalai, 1911. június 8. 4.

${ }^{11}$ Sastavljeno prema bibliografiji Eve Kelemen (Kelemen, 2015: 161-258). 